\title{
PENERAPAN METODE PEMBELAJARAN DISKUSI \\ DAN RESITASI DALAM MENINGKATKAN HASIL BELAJAR PENDIDIKAN AGAMA HINDU SISWA KELAS IV SD NEGERI 2 TUMBU KARANGASEM
}

\author{
Oleh \\ Ida Ayu Putu Suci Lestari \\ SD Negeri 2 Tumbu Karangasem
}

Diterima 29 Desember 2017, direvisi 29 Januari 2018, diterbitkan 28 Pebruari 2018

\begin{abstract}
This study aims: (1) to know the application of the use of methods of discussion and recitation can improve the learning outcomes of Hindu religious education fourth graders Elementary School 2 Tumbu. (2) to find out constraints faced in using the method of assignment and recitation in the learning of Hindu religious education fourth grade students of SD Negeri 2 Tumbu.

The type of this research is Classroom Action Research (PTK) with the subject of this research is the fourth grader of SD Negeri 2 Tumbu, the Hindu of 17 people from 22 students, consist of 10 men, and 7 women. The research was conducted at SD Negeri 2 Tumbu Karangasem. This research was conducted in two cycles. One cycle consists of preparation, execution, observation and reflection. Data collection is done by test method. Then the data is analyzed by quantitative descriptive technique.

The results of this study is an increase in learning outcomes, the initial reflection of the average learning outcomes of Hindu religious education amounted to 54.7 with 29,41\% complete learning. Then, in the first cycle the average learning outcomes of Hindu religious education increased to 69.4 and the classical completeness of $64.71 \%$ is still less than the classical completeness set $85 \%$. Thus, learning in cycle I has not been completed. In cycle II the average learning outcomes of Hindu religious education increased to 79.1 and $100 \%$ classical completeness, thus the learning cycle II completed.
\end{abstract}

Keywords: Discussion and Achievement Learning Methods, Learning Outcomes 


\section{PENDAHULUAN}

Interaksi dalam pembelajaran akan terjadi secara menarik jika pembelajaran dapat bermakna bagi siswa. Pembelajaran bermakna akan terjadi apabila proses pembelajaran dilaksanakan secara menyenangkan. Proses pembelajaran yang menyenangkan akan tercipta jika melibatkan siswa secara aktif dalam pembelajaran. Permen diknas No. 41 tentang standar proses menuntut proses pembelajaran hendaknya berpusat pada siswa dan dikemas secara menyenangkan.

Kenyataan di lapangan di SD Negeri 2 Tumbu, harapan yang tersirat dalam tuntutan kompetensi belum bisa terpenuhi. Sebagian besar masih mengalami kesulitan dalam mengajarkan pengetahuan yang tercermin dari hasil belajar dibawah nilai KKM, keterampilan siswa masih rendah serta sikap spiritual dan sosial masih kurang baik. Dari 21 orang siswa yang mengikuti test refleksi awal yaitu 17 orang, dikarenakan 4 orang yang lain adalah beragama Islam, mengingat penelitian ini merupakan penelitian untuk mata pelajaran pendidikan agama Hindu. Pada refleksi awal, berdasarkan hasil belajar yang diperoleh, maka hasil belajar siswa masih dikategorikan kurang yaitu 58,53 sehingga daya serap yang duperoleh $58,53 \%$. Karena rata-rata hasil belajar siswa yang diperoleh oleh siswa bila dikonversikan dengan pedoman terletak pada rentangan $40 \mathrm{~d}$ " $\mathrm{M}<$ 55.

Kriteria Ketuntasan Minimal (KKM) di kelas IV untuk mata pelajaran pendidikan Agama Hindu adalah 70, jadi untuk mencari ketuntasan belajar menggunakan patokan nilai e" 70.Banyaknya siswa yang memperoleh e" 70 adalah 7 orang atau $41,18 \%$. Hal itu sangat jauh dari yang diharapkan, karena untuk mencapai hasil yang optimal ketuntasan belajar siswa diharapkan mampu mencapai $\geq 75 \%$ atau setidaknya mencapai ketuntasan secara menyeluruh $100 \%$.

Disamping itu guru dalam menyajikan materi semata-mata hanya berorientasi pada materi yang tercantum dalam kurikulum dan buku teks,sehingga kurang dikaitkan dengan pengalaman dan pengamatan siswa dalam kehidupan sehari hari.Siswa masih bersikap pasif, dimana hanya sebagai pendengar saja,

Berdasarkan kenyataan tersebut, Salah satu cara yang dapat ditempuh adalah merubah motode pembelajaran. Metode pemebelajaran yang berpusat pada guru sedikit demi sedikit digeser pada pembelajaran yang berpusat pada siswa. Sehubungan dengan permasalahan di atas, maka upaya peningkatan kualitas proses belajar mengajar dalam pembelajaran Pendidikan Agama Hindu merupakan suatu kebutuhan yang sangat mendesak untuk dilakukan.Salah satu metode pembelajaran yang diduga dapat menjembatani keresahan tersebut adalah metode diskusi dan resitasi. Metode ini merupakan salah satu metode pembelajaran yang lebih menekankan pada upaya siswa untuk belajar memecahkan terhadap suatu masalah yang diberikan oleh guru dalam suatu medium dialog langsung antara siswa dengan guru antara siswa dengan siswa.Siswa dipancing untuk mampu bertanya dan menyampaikan pedapat baik kepada guru maupun siswa.Dengan metode metode diskusi dan resitasi ini diharapkan siswa lebih aktif sehingga hasil belajar dapat ditingkatkan.

Untuk itu penelitian ini diharapkan pada pengembangan metode diskusi dan resitasi dalam pembelajaran Pendidikan Agama Hindu di SD, melalui serangkaian tindakan yang terencana, terarah, bertujuan, dan terprogram dalam dimensi penelitian tindakan kelas (PTK) untuk mengatasi beberapa masalah yang dihadapi dalam pembelajaran Pendidikan Agama Hindu di Kelas IV SD Negeri 2 Tumbu dengan judul "Penerapan Metode Pembelajaran Diskusi dan Resitasi Dalam Upaya Meningkatkan Hasil Belajar Pendidikan Agama Hindu Siswa Kelas IV SD Negeri 2 Tumbu Karangasem"

Permasalahan dalam penelitian ini. Apakah penerapan metode diskusi dan resitasidapat 
meningkatkan hasil belajar pendidikan agama Hindu siswa kelas IV SD Negeri 2 Tumbu Semester Genap Tahun Pelajaran 2014/2015. Tujuan Penelitian untuk mengetahui penerapanpenggunaan metode diskusi dan resitas idalam upaya meningkatkan hasil belajar pendidikan agama Hindu siswa kelas IV SD Negeri 2 Tumbu semester genap tahun pelajaran 2014/2015.

Adapun manfaat teoretis dalam penelitian ini yaitu menambah kasanah ilmu pengetahuan khususnya dalam bidang paedagogik tentang metode diskusi dan resitasi dapat meningkatkan hasil belajar pendidikan agama Hindu siswa kelas IV Sekolah Dasar.Manfaat Praktis Bagi para guru pendidikan agama Hindu diharapkan dapat dijadikan masukan dalam memperluas pengetahuan dan wawasan mengenai model dan metode pembelajaran dalam mengajar pendidikan Agama Hindu untuk meningkatkan kualitas atau hasil pembelajarannya. Bagi lembaga atau sekolah sebagai sumbangan pemikiran dalam rangka mencari alternatif model dan metode pembelajaran yang dianggap baik dan sesuai untuk meningkatkan kualitas pembelajaran pendidikan Agama Hindu pada jenjang Sekolah Dasar.

Penelitian penerapan metode pembelajaran diskusi dan resitasi dalam upaya meningkatkan hasil belajar pendidikan agama Hindu siswa kelas IV SD Negeri 2 Tumbu Karangasem menggunakan tinjauan pustaka yakni; metode diskusi, metode resitasi dan hasil belajar.

Diskusi adalah suatu proses penglihatan dua atau lebih individu yang berinteraksi secara verbal dan saling berhadapan muka mengenai tujuan atau sasaran yang sudah ditentukan melalui cara tukar menukar informasi, mempertahankan pendapat, atau pemecahan masalah. Sedangkan metode diskusi kepada siswa (kelompok-kelompok siswa) untuk mengadakan perbincangan ilmiah guna mengumpulkan pendapat, membuat kesimpulan, atau menyusun berbagai alternatif pemecahan atas suatu masalah (Taniredja, 2011: 23).

Yusuf (1995:67) menyatakan resitasi berasal dari bahasa inggris yaitu to cite yang artinya mengutip dan re= kembali adalah siswa mengutip atau mengambil sendiri bagian-bagian pelajaran itu dari buku-buku tertentu lalu belajar sendiri dan berlatih sampai siap sebagaimana mestinya. Dengan kata lain yang dimaksud dengan metode resitasi adalah guru menyajikan bahan pelajaran dengan cara memberikan tugas kepada siswa untuk dikerjakan dengan penuh rasa tanggung jawab.

Metode pemberian tugas belajar atau resitasi yang sering disebut metode pekerjaan rumah adalah suatu metode dimana siswa diberi tugas khusus diluar jam pelajaran. Menurut Uzer Usman dan Lilis Setiawati bahwa metode resitasi atau pemberian tugas adalah suatu cara penyajian pelajaran dengan cara guru memberi tugas tertentu kepada siswa dalam waktu yang telah ditentukan dan siswa mempertanggung jawabkan tugas yang dibebankan kepada siswa (1993 : 128).

Sedangkan Syaiful Bahri Djamarah dan Aswan Zain (1996 :53) mendefinisikan bahwa metode resitasi atau penugasan adalah metode penyajian bahan dimana guru memberikan tugas tertentu agar siswa melakukan kegiatan belajar. Dari beberapa pendapat yang telah dikemukakan diatas, dapat diambil suatu kesimpulan bahwa metode resitasi atau pemberian tugas adalah suatu cara penyajian bahan pelajaran dimana guru memberikan tugas-tugas tertentu kepada siswa untuk dikerjakan agar siswa melakukan kegiatan belajar dengan adanya alokasi waktu yang telah ditentukan agar siswa dapat mempertanggungjawabkan tugas tersebut kepada guru.

Tujuan belajar adalah membelajarkan siwa, agar mengkonstruksi pengetahuan-pengetahuan yang ada dibenak mereka melalui proses asimilasi dan akomodasi. Mulyasa (2006:98), mengatakan bahwa :untuk mengajar dengan 
baik, guru melaksanakan serangkaian kegiatan mengajar yang terdiri dari 1) tahap perencanaan, 2) tahap pelaksanaan / proses belajar mengajar, dan 3) tahap evaluasi dan penyempurnaan. Ketiga tahapan di atas tersebut harus dikelola dan dilaksanakan dengan sebaik mungkin agar tujuan yang diinginkan dapat tercapai. Setiap kegiatan belajar akan berakhir dengan hasil belajar.

Skinner (dalam Suthedja, 2001:73) menyebutkan bahwa : "hasil belajar meliputi keterampilan dan kebiasaan, seperti keterampilan di bidang seni, kreativitas, bakat, perbedaan individu dalam belajar"'. Hasil belajar adalah salah satu tujuan yang hendak dicapai dalam proses belajar. Dari rujukan Srijanti (1997 :70) yang menyatakan bahwa : "Hasil Belajar atau hasil belajar yaitu kemampuankemampuan yang menjadi milik kita setelah proses belajar berlangsung". Senada dengan Nasution (2006:68) yang menyatakan bahwa: "hasil belajar adalah penguasaan seseorang terhadap pengetahuan atau keterampilan tertentu dalam suatu mata pelajaran, yang lazim diperoleh dari nilai tes atau angka yang diberikan guru". Selanjutnya Sardiman (2003:29) menekankan bahwa proses belajar dalam diri siswa dapat dikatakan baik apabila dalam diri siswa terjadi perubahan dalam aspek kogitif : keilmuan dan pengetahuan, konsep atau fakta, afektif : personal, kepribadian atau sikap dan psikomorik : kelakuan, keterampilan dan penampilan. Ketiga hasil tersebut terangkum dalam hasil belajar. Menurut Nurkancana dan Sunartana (1990:2) mengemukakan bahwa :Hasil belajar (School achievement) adalah hasil yang dicapai oleh individu setelah individu yang bersangkutan menjalani suatu proses belajar atau diajarkan pengetahuan tertentu. Hasil belajar ini biasanya disebut juga kecakapan nyata, kecakapan aktual (actual ability) yang diperoleh seseorang setelah ia belajar sesuatu pengetahuan tertentu.

Jadi hasil belajar adalah hasil yang dicapai oleh individu setelah mengalami suatu proses belajar dalam jangka waktu tertentu. Hasil yang dimaksud dalam penelitian ini adalah kecakapan nyata karena hasil belajar ini dapat dilihat secara nyata yaitu berupa nilai.

\section{METODE}

\subsection{Rancangan Penelitian}

Penelitian ini merupakan Penelitian Tindakan Kelas (PTK) yang dilaksanakan di kelas secara sistematis dengan mengikuti prosedur tertentu. Dalam penelitian ini akan direncanakan dua siklus, dimana setiap siklus akan dilakukan dalam empat tahapan yang berbeda yang terdiri dari perencanaan, pelaksanaan tindakan, observasi-evaluasi, dan refleksi.

Adapun rancangan dari penelitian tindakan kelas (PTK) ini dapat digambarkan pada gambar 1.

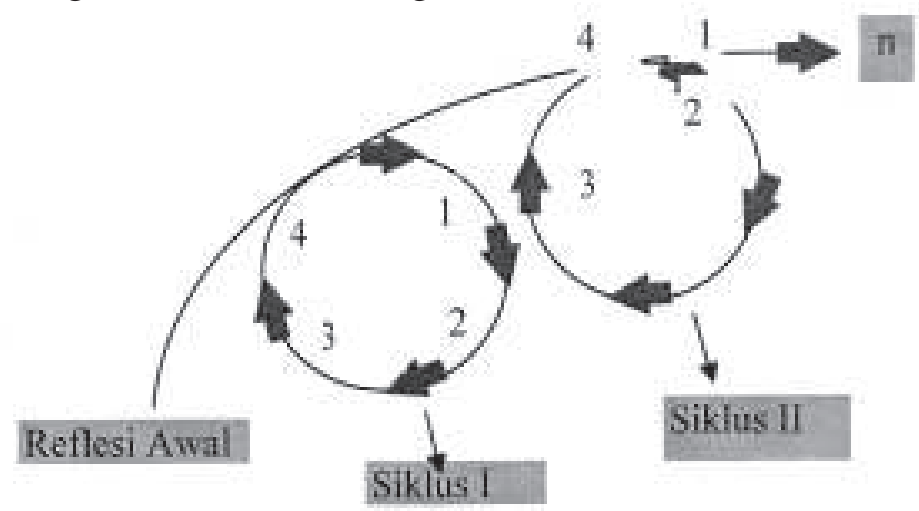

Gambar 01. Siklus penelitian tindakan kelas

Kemmis dan Mc. Taggart (dalam Arikunto, 2006:93)

Penerapan Metode Pembelajaran Diskusi dan Resitasi Dalam Meningkatkan Hasil Belajar Pendidikan Agama Hindu Siswa Kelas IV ..... | Ida Ayu Putu Suci Lestari 
Keterangan :

1. Tahap Perencanaan

2. Tahap Pelaksanaan

3. Tahap Observasi/Evaluasi

4. Refleksi

\subsection{Subjek Penelitian dan Objek Penelitian}

Subjek penelitian ini adalah siswa Kelas IVSemester genap SD Negeri 2 Tumbu, semester genap tahun Pelajaran 2014/2015 yang beragama Hindu yang berjumlah 17 orang, terdiri dari 11 orang laki-laki, dan 6 orang perempuan. Objek penelitian ini adalah hasil belajar mata pelajaran pendidikan agama Hindusiswa dengan penerapan metode pembelajaran diskusi dan resitasi

\subsection{Prosedur Penelitian}

Jenis peneltian tindakan kelas ini dilakukan dalam dua siklus. Siklus I dan siklus II yang didahului dengan refleksi awal. Dalam setiap siklus dibagi menjadi 4 tahap kegiatannya yang meliputi perencanaan, tindakan, observasi dan evaluasi, serta refleksi.

\subsection{Metode Pengumpulan Data dan Instrumen Penelitian}

Metode tes dilakukan setelah pembelajaran metode diskusi dan resitasi berlangsung. Kemudian, dibuat kesimpulan hasil tes dan dinilai sesuai pedoman kriteria penilaian yang telah ditentukan, seperti pada tabel 1 .

\subsection{Teknik analisis Data}

Teknik analisis data pada penelitian ini bertujuan untuk menentukan hasil belajar Pendidikan Agama Hindu siswa kelas IV SD Negeri 2 Tumbu tahun Pelajaran 2014/ 2015.Data hasil belajar siswa diolah dengan rumus berikut.

1) Hasil tes individu siswa diperoleh dengan menggunakan rumus berikut.

$$
X=\frac{\text { Jumlah benar }}{\text { Jumlah seluruh soal }} \times 100
$$

Ket: $X=$ Nilai Individu siswa Kualifikasi pencapaian Hasil belajar/KKM ditentukan dengan kriteria berikut,

$$
\begin{aligned}
85 & \leq \mathrm{M} \leq 100 \rightarrow \text { Sangat baik } \\
70 & \leq \mathrm{M}<85 \rightarrow \text { Baik } \\
55 & \leq \mathrm{M}<70 \rightarrow \text { Cukup } \\
40 & \leq \mathrm{M}<55 \rightarrow \text { Kurang } \\
0 & \leq \mathrm{M}<40 \rightarrow \text { Sangat Kurang } \\
& \quad(\text { STKIP Singaraja,1999:28) }
\end{aligned}
$$

2) Daya serap siswa diperoleh dengan rumus berikut.

$$
\mathrm{DS}=\frac{\text { Nilai Rata- rata Kelas }}{\text { Nilai Tertinggi ideal (100) }} \times 100
$$

3) Siswa dikatakan tuntas jika memperoleh nilai 70 ke atas, sehingga Ketuntasan klasikal siswa diperoleh dengan rumus :

\section{Tabel 1. Rubrik Penilaian Jawaban Siswa}

\begin{tabular}{lccc}
\hline Kriteria & Jumlah Soal & Skor Masing-masing soal & Jumlah \\
\hline Tes Pilihan ganda & 20 & 5 & 100 \\
\hline Total & 20 & 5 & 100 \\
\hline
\end{tabular}




$$
\mathrm{KKB}=\frac{\text { Jumlah siswa tuntas }}{\text { Jumlah siswa keseluruhan }} \times 100 \%
$$

Keterangan:

$\mathrm{KKB}=$ Kriteria Ketuntasan Belajar

(Depdiknas, 2003: 72)

\subsection{Metode Analisis Data}

Untuk menentukan rata-rata aktivitas belajar siswa digunakan rumus berikut.

$$
\mathrm{M}=\frac{\sum \mathrm{X}}{\mathrm{N}}
$$

Keterangan:

$\sum \mathrm{X}=$ Jumlah Skor

$\mathrm{M}=$ Mean atau nilai rata-rata

$\mathrm{N}=$ Jumlah individu

Berdasarkan indikator aktivitas dapat diketahui bahwa skor maksimum idealnya adalah 18 , sedangkan skor minimum idealnya adalah 6. Rumus kriteria kualitas aktivitas tersebut dapat dijelaskan sebagai berikut.

$\mathrm{Mi}=$ Mean ideal

Mi diperoleh dengan menggunakan rumus sebagai berikut.

$\mathrm{Mi}=1 / 2($ skor maksimal ideal + skor minimum ideal)

SDi $=$ Standar Deviasi Ideal

SDi diperoleh dengan menggunakan rumus sebagai berikut.

$\mathrm{SDi}=1 / 6$ (skor maksimal ideal - skor minimum ideal)

Selanjutnya, data aktivitas siswa diperoleh melelui rumus konversi aktivitas berikut.
Berdasarkan rumus di atas, diperoleh klasifikasi kategori aktivitas belajar siswa melalui penghitungan berikut

$$
\begin{aligned}
\mathrm{Mi} & =1 / 2(18+6) \\
& =1 / 2 \times 24=12 \\
\mathrm{SDi} & =1 / 6 \times(18-6) \\
\mathrm{SDI} & =1 / 6 \times 12=2
\end{aligned}
$$

\section{HASIL PENELITIAN}

Berdasarkan hasil analisis data pada refleksi awal, rata-rata hasil belajar sebesar 58,53 dengan kategori kurang, hal ini disebabkan karena: 1) guru dalam menyajikan materi semata-mata hanya berorientasi pada materi yang tercantum dalam kurikulum dan buku teks, sehingga kurang dikaitkan dengan pengalaman dan pengamatan siswa dalam kehidupan sehari hari, 2) bagi siswa belajar tampaknya untuk menghadapi ulangan dan lepas dari kehidupan nyata mereka, 3) siswa kurang termotivasi untuk belajar dan mengemukakan pendapat serta masalahnya pada saat pembelajaran.

Kemudian pada siklus I, rata-rata skor hasil belajarPendidikan Agama Hindumeningkat menjadi 72,35 dengan kategori cukup. Hasil itu menunjukkan telah memenuhi syarat sesuai yang diharapkan dalam penelitian ini. Namun secara klasikal ketuntasannya masih ada dibawah standar yang diharapkan, ketuntasan belajar secara klasikal pada siklus I hanya sebesar 64,71\% masih lebih kecil dari yang diharapkan sebesar 75\%. Dari hasil refleksi pada siklus I, terdapat hambatan-hambatan

Tabel 2. Rumus Konversi Aktivitas Belajar Siswa

\begin{tabular}{llc}
\hline No & Kriteriakualitas & Kategori \\
\hline 1 & $\mathrm{Mi}+1 \mathrm{SDi} \leq \mathrm{x} \leq \mathrm{Mi}+3 \mathrm{SDi}$ & SangatAktif \\
2 & $\mathrm{Mi}-1 \mathrm{SDi} \leq \mathrm{x}<\mathrm{Mi}+1 \mathrm{SDi}$ & Aktif \\
3 & $\mathrm{Mi}-3 \mathrm{SDi} \leq \mathrm{x}<\mathrm{Mi}-\mathrm{Sdi}$ & KurangAktif \\
\hline
\end{tabular}

Dantes dalam Dwija (2006:103) 
menyebabkan belum tercapainya hasil yang diharapkan, yaitu : (1) Ada beberapa siswa yang belum sungguh-sungguh bekerja dalam kelompok. Dari hasil pengamatan dan wawancara, siswa yang memiliki kemampuan lebih dalam kelompoknya masih ragu dan malu membimbing teman-temannya: (2) Pada saat menghadapi tes, masih banyak siswa yang kurang siap dan percaya diri dan hanya ad abeberapa siswa yang berani menanyakan permasalahan yang belum dipahami.

Berdasarkan kendala-kendala/ permasalahan yang dialami pada siklus I,maka pada siklus II dilakukan upaya untuk mengobati/memperbaiki kendala itu dengan cara: (1) Peneliti kembali memperbaiki kelompok agar lebih heterogen baik kemampuan akademis maupun jenis kelamin ,dan memotivasi agar anak yang lebih mampu tidak ragu dan malu-malu untuk membimbing temannya.Untuk lebih memotivasi pada siklus II peneliti memilih salah satu kelompok sebagai kelompok terbaik jika dapat menyelesaikan kegiatan dengan baik dan tepat waktu. (2) Peneliti memberikan arahan agar siswa tidak malu dan takut bertanya baik pada guru maupun teman, jika ada permasalahan yang tidak dapat dipecahkan. Selain itu sebelum tes dimulai peneliti juga memberikan kesempatan pada siswa untuk bertanya tentang materi yang belum jelas. Dengan adanya siklus I hasil pada refleksi awal dapat ditingkatkan dari rata-rata hasil belajar 58,53 menjadi 72,35 dan ketuntasan belajar dari 41,18 menjadi $64,71 \%$.

Setelah meninjau dan memperbaiki kendala-kendala pada siklus I, pembelajaran pada siklus II tampak lebih baik, aktif dan menyenangkan sehingga semua siswa kelihatan aktif dalam mencari penyelesaian lewat diskusi, hal ini berdampak pada hasil yang diperoleh. Rata-rata skor hasil belajarPendidikan Agama Hindumeningkat dari 72,35 dengan kategori cukup pada siklus I menjadi sebesar 81,18 dengan kategori baik/terlampaui pada siklus II. Ketuntasan belajar klasikal juga meningkat dari $64,71 \%$ (belum tuntas) pada siklus I menjadi sebesar $94,12 \%$ (tuntas) pada siklus II.

Berdasarkan hasil pembelajaran dan analisis hasil pembelajaran tersebut di atas, dapat disimpulkan sebagai berikut: Penerapan metode diskusi dan resitasi dalam pembelajaranPendidikan Agama Hindu dapat meningkatkan hasil belajarPendidikan Agama Hindu siswa Kelas IV SD Negeri 2 Tumbu. Rata-rata skor hasil belajar pendidikan Agama Hindu meningkat dari 672,35 dengan kategori cukup/tuntas pada siklus I menjadi sebesar 81,18 dengan kategori baik/terlampaui pada siklus II. Ketuntasan belajar klasikal juga meningkat dari 64,71\% (belum tuntas) pada siklus I menjadi sebesar $94,12 \%$ (tuntas) pada siklus II bagi siswa

Penerapan metode diskusi dan resitasi ini dapat memberikan pengalaman bagi siswa untuk dapat berfikir kreatif dan tanggung jawab atas pembelajaran yang telah dilakukannya.Bagi GuruHasil penelitian ini dapat dipakai sebagai salah satu alternatif dalam memilih model pembelajaran sebagai upaya meningkatkan hasil belajar siswa. Sebagai pedoman dalam mengajarPendidikan Agama Hindu untuk merancang suatu model pembelajaranPendidikan Agama Hindu yang lebih inovatif dan sebagai alternatif agar pembelajaran lebih efektif dan menyenangkan.

\section{DAFTAR PUSTAKA}

Alwi, Hasan (eds). 2005. Kamus Besar Bahasa Indonesia. Jakarta : Balai Pustaka.

A.Tabrani R. 1993a. Proses Belajar Mengajar Yang Efektif Tingkat Pendidikan Dasar. Bandung: Bina Budhaya.

Alipandie, Imansyah. 1984. Didaktik Metodik Pendidikan . Surabaya: Penerbit Usaha Nasional. 
Arikunto, Suharsimi. 2006a. Prosedur Penelitian Suatu Pendekatan Praktik. Jakarta : PT. Rineka Cipta.

Aqib, Zaenal. 2014. Model-Model, dan Strategi Pembelajaran Kontekstual (Inovatif). Bandung: CV Yrama Widya.Djamarah, S.B., Aswan Zain. 2002. Strategi Belajar Mengajar. Jakarta: PT. Rineka Cipta

Dwija, I Wayan. 2003a. Petunjuk Penyusunan Proposal (Buku Ajar). Amlapura: STKIPAgama Hindu.

Engkoswara. 1984. Dasar - Dasar Metodologi Pengajaran. Jakarta: Bina Aksara

Herawan, K. D., \& Sudarsana, I. K. (2017). Relevansi Nilai Pendidikan Karakter Dalam Geguritan Suddhamala Untuk Meningkatkan Mutu Pendidikan Di Indonesia. Jurnal Penjaminan Mutu, 3(2), 223-236.

Hertali Vita Pramanta. 2013. Pengaruh Pembelajaran Model Resitasi Terhadap Prestasi Belajar Siswa Pada Mata Pelajaran Sistem Kelistrikan Otomotif Di SMK Muhammadiyah 3 Yogyakarta.

Moh. Uzer Usman dan Lilis Setiawati. 1993. Upaya Mengoptimalisasi Kegiatan. Bandung: Remaja Rosda Karya

Mulyasa, E. 2006. Menjadi Guru Profesional. Bandung: PT. Remaja Rosdakarya.

Nasution, S. 2006. Berbagai Pendekatan Dalam Proses Belajar Mengajar. Jakarta: PT. Bumi Aksara.

Nurkancana, W., P.P.N. Sunartana. 1986. Evaluasi Pendidikan. Surabaya: Usaha Nasional.

Panji, G.N. 1983. Pokok-Pokok Observasi Kelas dan Simulasi. Singaraja: SPG Negeri Singaraja.
Purwanto, M.N, Ihmed Syarif. 1993. Tekhnik - Tekhnik Evaluasi Pendidikan. Surabaya: Roda Pengetahuan.

Radiana. K. 2007. Pengaruh Penerapan PendekatanMultiple Talent Dalam Pembelajaran Matematika Terhadap Prestasi Belajar Matematika Siswa Kelas XI SMANegeri 4 Singaraja. Skripsi Tidak Diterbitkan. Singaraja: Jurusan Pendidikan Matematika, IKIP Negeri Singaraja.

Sardiman A.M. 2003. Interaksi dan Motivasi Belajar Mengajar. Jakarta: PT. Raja Grafindo Persada.

Slameto. 2003. Belajar dan Faktor - Faktor Yang Mempengaruhinya. Jakarta: PT. Rineka Cipta.

Srijanti, O. 1997. Psikologi Pendidikan. Bandung: Pusat Pengembangan Penataran Guru Tertulis Depdikbud.

Subagyo, Joko. 1997. Metode Penelitian Dalam Teori dan Praktek. Jakarta : PT. Rineka Cipta.

Sudarsana, I. K. (2017). Interpretation Meaning of Ngaben for Krama Dadia Arya Kubontubuh Tirtha Sari Ulakan Village Karangasem District (Hindu Religious Education Perspective). Vidyottama Sanatana: International Journal of Hindu Science and Religious Studies, 1(1), 1-13.

Sudjana N., Ahmad Rivai. 1991. Media Pendidikan. Bandung: CV. Sinar Baru.

Sugiyono. 2007. Metode Penelitian Pendidikan. Bandung : Alfabeta.

Sukmadinata, N S. 2007. Metode Penelitian Pendidikan. Jakarta PT. Remaja Rosdakarya.

Suprayekti. 2003. Interaksi Belajar Mengajar. Jakarta: Depdiknas. 
Susilo, M. Joko. 2006. Gaya Belajar Menjadikan Makin Pintar. Yogyakarta: Pinus.

Suthedja, M.W. Dkk. 2001. Belajar dan Pembelajaran. Singaraja: IKIP Negeri Singaraja.

Taniredja, Tukiran. 2011. Model-model Pembelajaran Inovatif. Bandung : Alfabeta
Wibawa, B. 2003. Penelitian Tindakan Kelas. Jakarta: Jakarta: Depdiknas.

Yoni Hermawan. 2014. Penerapan Metode Resitasi Dan Diskusi Untuk Meningkatkan Prestasi Belajar Mahasiswa Program Studi Ilmu Keperawatan Universitas Galuh.

Yusuf, Tayar. 1995. Metodologi Pengajaran Agama dan Bahasa Arab . Jakarta : PT. Raja Grafindo Persada. 